\title{
Fuel Cells for Backup Power in Telecommunications Facilities
}

\author{
Providing a constant, reliable electric power supply
}

$\mathrm{T}$ elecommunications providers rely on backup power to maintain a constant power supply, to prevent power outages, and to ensure the operability of cell towers, equipment, and networks. The backup power supply that best meets these objectives is fuel cell technology.

\section{Why do providers need backup power?}

The telecommunications industry relies on an elaborate network of cell phone towers and field facilities to transmit phone calls and provide services. To operate effectively, each of these towers and field facilities requires a constant and highly reliable electrical power supply.

The industry transmits voice and electronic data through wired and wireless networks. To provide these services, facilities require substantial electrical power, which usually comes from the electrical grid but may also be converted to direct current (DC) power at -48 volts for wired networks and +24 volts for wireless networks. Adequate, effective backup power is essential because the electrical grid is subject to disruption by natural and man-made causes like extreme weather and power shortages.

As the telecommunications industry continues to expand rapidly, the increased use of cell phones, computers, and highspeed Internet requires an increase in the number of cell phone towers and field facilities needed to support these services. This expansion introduces new challenges, and service reliability through backup power sources remains at the forefront for industry providers. To prevent power outages, providers use redundancy and backup power sources.

\section{What backup power sources exist?}

When a tower or facility loses power from the grid, a backup power source must assume the site load. Most telecommunications facilities have at least eight-hour backupoften required by regulation - but locations prone to lengthy power outages, such as hurricane-prone areas, require backup capability between 24 and 72 hours. To accomplish this requirement, most providers use a combination of three backup power technologies: batteries, generators, and fuel cells.

\section{Batteries}

As the most-common source of backup power, batteries provide direct current (DC) power. Lead-acid batteries continually charge with grid power and provide the stored electricity as backup power until the grid is restored. Batteries can supply only as much power as they have stored, and severe weather conditions can hinder their operation.

\section{Generators}

Generators provide alternating current $(\mathrm{AC})$ power and can be automatically or manually activated. In remote, off-grid locations, generators may be used as general power sources.

\section{Fuel Cells}

Backup power fuel cells use proton electrolyte membrane (PEM) technology to provide DC power. PEM fuel cells are fueled directly by hydrogen, operate at low temperatures, are smaller than other fuel cells, and have a short warm-up time. Most PEM fuel cells have integral batteries or ultracapacitors to provide immediate power.

\section{Why are fuel cells the best backup power?}

Fuel cells are energy-conversion devices that can efficiently capture and use the energy-carrying capacity of hydrogen to power nearly every end-use energy need. Energy uses include portable devices, transportation vehicles, and stationary power stations, such as those used for the telecommunications industry.

Fuel cells are more effective than batteries for backup power because they last longer and are more predictable. Even though batteries have a five-year life expectancy, their capacity diminishes with time, and they can be ruined if their charge is drawn too often. Fuel cells, however, can operate for ten years or more with undiminished power quality and quantity.

Compared with generators, fuels cells are cleaner, quieter, pollute less, and require little on-site maintenance. Fuel cells 
are environmentally friendly because they convert the chemical energy in hydrogen directly to electricity with pure water and heat as the only by-products. Other advantages of fuel cells for backup power include:

$>$ Operating efficiencies around $50 \%$

Scalable and modular to operate in parallel

Wider operating temperature range $\left(-40^{\circ} \mathrm{F}\right.$ to $\left.122^{\circ} \mathrm{F}\right)$

Indoor or outdoor use with a minimal footprint

Longer life with no moving parts

\section{How are fuel cells installed?}

To support efficient permitting and safe operations at telecommunication sites that use fuel cell backup power, the U.S. Department of Energy works with codes organizations, local permitting officials, national laboratories, and industry experts to develop model codes and standards and to provide up-to-date information for everyone involved.

Figure 1 depicts a fuel cell power plant that provides backup power for a telecommunications site. The primary hazards are the hydrogen and stored electrical energy, which the codes and



Figure 1. Layout of a Fuel Cell Power Plant standards requirements address. The power plant consists of three components:

\section{Hydrogen Storage}

Fuel Cell Stack

Battery/Capacitor

\section{Hydrogen Storage}

Fuel cell installations are typically fueled by a six-pack of compressed hydrogen storage containers. These containers each hold either $139 \mathrm{scf}$ or $261 \mathrm{scf}$ of hydrogen at a pressure of 2,400 psi and a weight of $137 \mathrm{lbs}$. They have the combined capacity to power a fuel cell for 24-96 hours.

\section{Fuel Cell Stack}

A single fuel cell will not provide the required power for most applications. Therefore, multiple fuel cells, referred to as a stack, are linked together in a fuel cell power plant to meet the required power demand.

\section{Battery/Capacitor}

Fuel cell power plants used for backup power typically require a DC storage device to provide immediate power while the fuel cell powers up. PEM fuel cells power up quickly, but there is

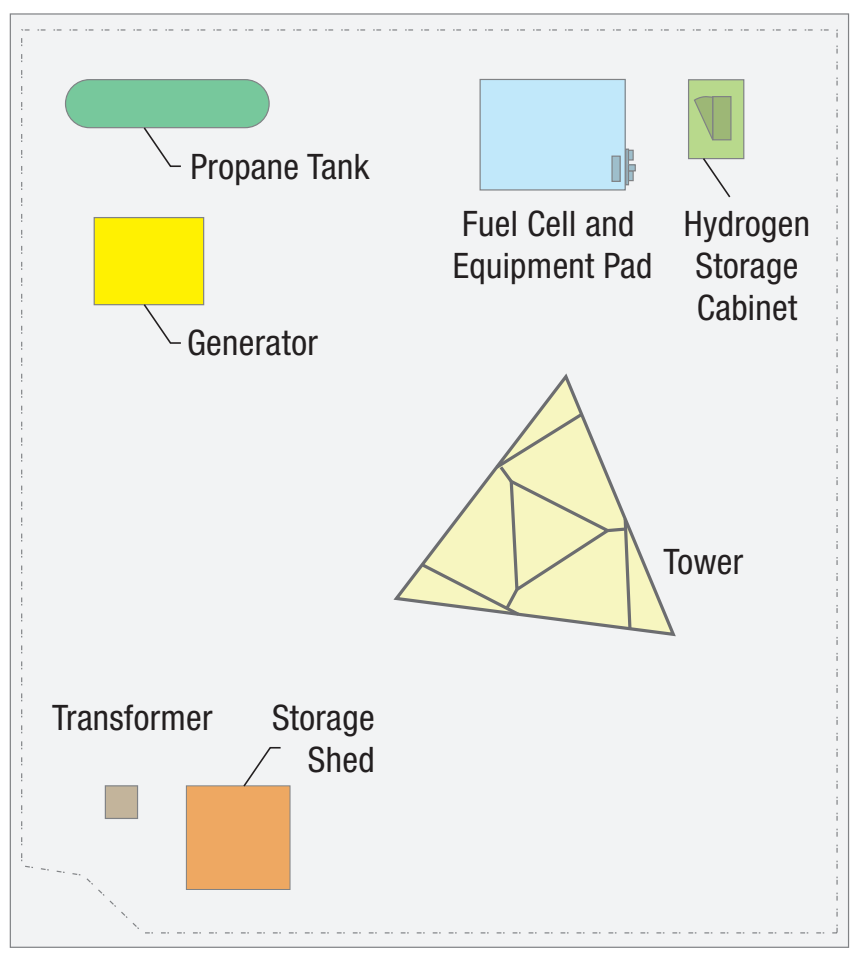
Equipment Pad Cabinet 
still a short period of time that requires the use of a battery or capacitor to supply power.

\section{How does hydrogen flow through the fuel cell?}

Figure 2 depicts a PEM fuel cell. In this fuel cell, hydrogen flows from the storage containers to the fuel cell. Air is also fed to the cell. At the anode, the hydrogen separates into a proton and an electron. The proton migrates across a membrane to the cathode where it reacts with the oxygen to form water. The electrons, which cannot pass through the membrane, flow from the cell to provide the needed electrical power.

\section{How do fuel cell power plants operate?}

Telecommunications installations with backup fuel cell power often incorporate fuel cells and batteries. As the system voltage changes, rectifiers or controllers switch between the primary power source and the backup power sources.

In the absence of grid power or another primary alternating current (AC) power source, the fuel cells, or a combination of fuel cells and batteries, provide direct current (DC) power to run the equipment. The fuel cells have internal batteries that provide temporary "bridge" power until the fuel cell reaches peak power production and takes over the load. When the primary power source is restored, the fuel cells shut down, and the load is returned to the primary source.

When the hydrogen fuel supply in a fuel cell is low, a selfchecking alarm remotely alerts the operator to replenish the storage containers. The operator can resupply the fuel cell via "hot swapping" or "bumping." In a "hot-swap" resupply, operators deliver pre filled hydrogen storage containers to the site and swap them individually with the depleted containers without disrupting backup operations. "Bump" resupply involves refilling the storage containers at the site. A hydrogen tanker delivers hydrogen gas and replenishes the existing storage supply.

\section{Do fuel cell power plants require maintenance?}

Fuel cells used for telecommunications backup power require less maintenance than batteries or generators, but they do require periodic maintenance. Some vendors maintain fuel cell backup power systems annually. The fuel cell power plant performs self-maintenance, and operators can configure the units to run unattended conditioning cycles to ensure operability. The operator determines the frequency of selftests, but manufacturers recommend one-month cycles.

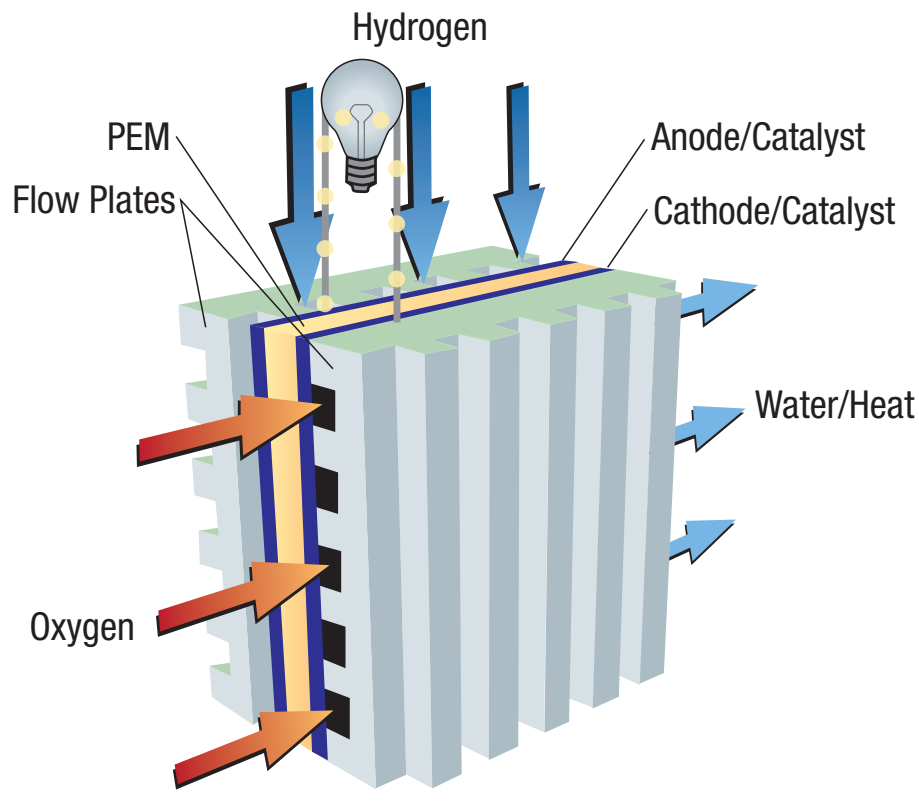

Figure 2. Schematic of a PEM Fuel Cell

\section{What are the codes and standards requirements?}

Most U.S. jurisdictions adopt a building fire code that sets construction and fire safety requirements. In most states, the International Building Code (IBC) and the International Fire Code (IFC) set requirements for fuel cell power plant installations for the telecommunications industry. The IFC directs permit applicants to two National Fire Protection Agency (NFPA) documents that contain requirements specifically applicable to stationary fuel cell power plants:

NFPA 853 Standard for the Installation of Stationary Fuel

Cell Power Plants

NFPA 55 Compressed Gases and Cryogenic Fluids Code

NFPA 853 refers to the National Electric Code for area classification requirements as well as Article 692, which sets electrical safety requirements for fuel cells. This document sets installation requirements organized according to the following chapters:

Chapter 4: General Equipment Configuration

Chapter 5: Siting and Interconnections

Chapter 6: Fuel Supplies and Storage Arrangements

Chapter 7: Ventilation and Exhaust

Chapter 8: Fire Protection

Chapter 9: Fuel Cell Power Systems $50 \mathrm{~kW}$ or Less

NFPA 55 sets requirements for the storage of hydrogen at a site, including separation distances from exposures. 


\section{Additional Resources}

For more information about telecommunications fuel cell use, visit the following Web sites:

\section{Government Web Sites}

$>$ http://www.h2bestpractices.org/ — Best Practices for Hydrogen Safety

http://www.hydrogen.energy.gov/safety.html — Hydrogen Safety

$>$ http://hydrogen.dot.gov/ — Department of Transportation (DOT) Hydrogen Portal

http://www1.eere.energy.gov/hydrogenandfuelcells/codes/permitting_guides.html — Permitting Guidelines

\section{Industry Web Sites}

$>$ http://www.hydrogenandfuelcellsafety.info/ - Hydrogen and Fuel Cell Safety

http://www.usfcc.com/about/standards.html — US Fuel Cell Council

http:/hcsp.us/default.aspx - Hydrogen Codes and Standards Portal

http://fuelcellstandards.com/ - Hydrogen Fuel Cell Codes and Standards

\section{Web Site}

DOE: www.hydrogen.energy.gov

Have a basic question about hydrogen or fuel cell technologies?

Need printed copies of documents?

Call the Energy Efficiency and Renewable Energy (EERE) Information Center at 877-EEREINF(0) / 877-337-3463 or submit your question or request online at www.eere.energy.gov/ informationcenter

Increase Your H2IQ!

Visit www.hydrogen.energy.gov

Prepared by NREL, a national laboratory of the U.S. Department of Energy, Office of Energy Efficiency and Renewable Energy, operated by the Alliance for Sustainable Energy, LLC. 